Tibuana

Journal of applied Industrial Engineering-University of PGRI Adi Buana

p-ISSN 2622-2027

DOI : https://doi.org/10.36456/tibuana.4.02.3749.65-68

$e$-ISSN 2622-2035

\title{
Distribution Route of Cement 40's kg Package at PT.XYZ using Saving Matrix
}

\author{
Nur Rahmawati ${ }^{1}$, Sinta Dewi ${ }^{2}$, M. Dicky Perdana Putra ${ }^{3}$ \\ ${ }^{1,2,3}$ Industrial Engineering Department , Faculty of Engineering, UPN "Veteran" Jawa timur \\ rahmawatinur1987@gmail.com
}

\begin{abstract}
Determining the distribution route is one important thing that must be considered by the company to get a cheaper product selling price. PT. XYZ is a cement manufacturing company with consumers spread across several regions. Due to the large number of consumers that must be supplied, the company has problems in determining product distribution routes that can produce a low total cost of distribution. In this method, the saving matrix method is used to obtain distribution routes that can produce the minimum distribution costs. From the results of the study, four sub routes of product distribution were found with distance savings of $1176 \mathrm{Km}$.
\end{abstract}

Index Terms-About; Cement; Distribution routes; Saving matrix; Vehichle routing problem.

\section{INTRODUCTION}

Transportation and distribution management play an important role in logistic management [1]. Transportation dan distribution costs contribute a sizeable portion to product costs [2] as well as significantly aggravating air pollution [3] and [4]. Determination of distribution routes is important because consumers want products at reasonable and competitive prices [5]. Therefore, companies that used to compete in terms of their business are now starting to switch to competition in terms of logistics [6].

PT. $X Y Z$ is a national private company engaged in the manufacturing industry that produces cement. This company was once managed by a world-class cement supplier company from Switzerland which has now been acquired most of its share by the government. PT. XYZ has several plants including the Narogong Plant, Cilacap Plant and Tuban Plant. The main consumer of PT. XYZ, namely PT.
Bumi Pembangunan Pertiwi, PT. Mataram Agung, PT. Makmur Jaya Berkat Bersama and several others spread across Central and East Java. In this study, the object of research is only limited to the Tuban Plant.

The problem currently faced by the company is in terms of product distribution. The problems faced by the company are categorized as CVRP (Capacitated vehicle routing problems) problems. CVRP is development of travelling saleman problem where the transportation vehicle used has a capacity limitation [7]. To solve the problems faced, in this study the saving matrix method is used. Saving matrix is a heuristic method that is usually used to find the distribution route of a product [8]. Saving matrix has a very simple algorithm so that it is easy to apply to vrp problems. This method was chosen because this method is proven to be able to solve the CVRP problem with optimal results as has been done in previous studies.

Previous studies that have used this method include: [9] which uses the method to generate distribution routes based on the google map, in addition there are [10] and [11] which use the same method to obtain optimal distribution routes.

\section{RESEARCH METHODOLOGY}

The method used in this research is the saving matrix method. The saving matrix steps can be seen in the Figure 1 below [12]:

A. The assumptions used are:

1. Road conditions during delivery are considered normal and there are no traffic jams due to accidents or natural disasters.

2. Vehicles only carries single type of product.

3. The route taken is a highway route that can be accessed by 4-wheeled vehicles with 
Tibuana

Journal of applied Industrial Engineering-University of PGRI Adi Buana

DOI : https://doi.org/10.36456/tibuana.4.02.3749.65-68

$p$-ISSN 2622-2027

$e$-ISSN 2622-2035

JBI class III.

B. The limitations used are:

1. The research is only applied to product that used land mode distribution.

2. The type of fleet used in the distribution of
GU $40 \mathrm{~kg}$ cement products is a 32 ton trailer type truck with 5 axles.

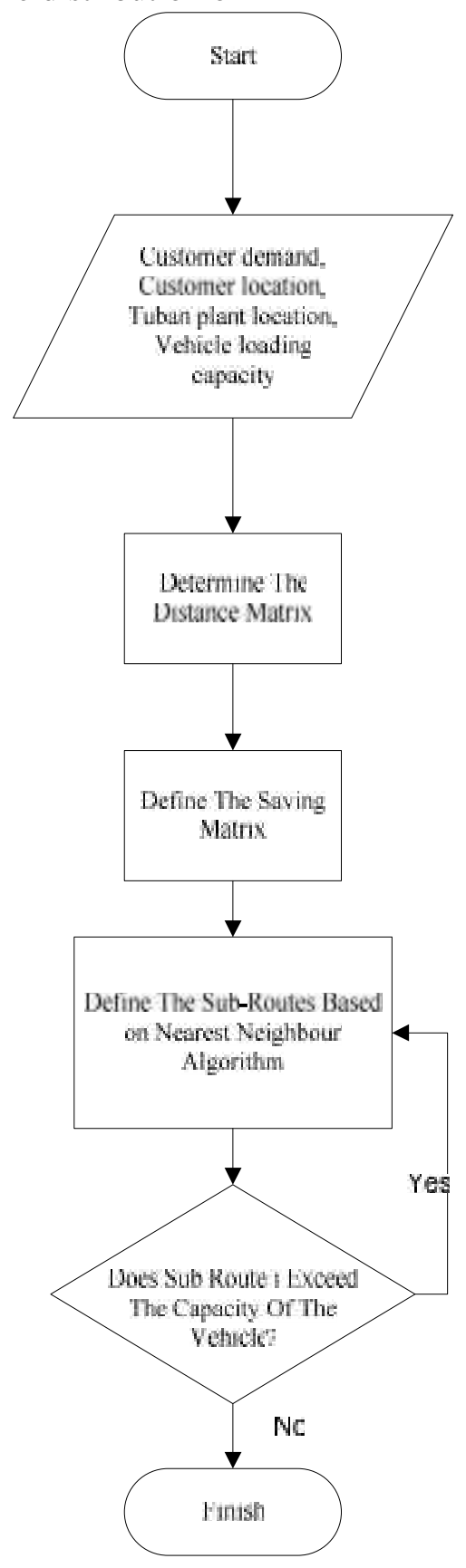

Figure 1: Black and white figure 


\section{Tibuana}

Journal of applied Industrial Engineering-University of PGRI Adi Buana

DOI : https://doi.org/10.36456/tibuana.4.02.3749.65-68

The distance matrix can be determined using the following equation:

$$
L_{1,2}=\sqrt{\left(X_{2}-X_{1}\right)^{2}+\left(Y_{2}-Y_{1}\right)^{2}}
$$

(1)

$$
\text { Where: } D_{1,2} \quad=\text { Distance for location }
$$

$$
\left(X_{2}, Y_{2}\right) \quad=\text { Destination location }
$$

\section{RESULT AND DISCUSSIONS}

Based on the results of calculations using equation (1), the distance matrix is obtained as in Table 1.

1 to 2

\begin{tabular}{|c|c|c|c|c|c|c|c|c|}
\hline Origin/Destination & Bojonegoro & Malang & Surabaya & Sidoarjo & Tulungagung & Kediri & Jember & Mojokerto \\
\hline Bojonegoro & 0 & & & & & & & \\
\hline Malang & 111,3 & 0 & & & & & & \\
\hline Surabaya & 111,7 & 237 & 0 & & & & & \\
\hline Sidoarjo & 109,3 & 270 & 238 & 0 & & & & \\
\hline Tulungagung & 111,3 & 370 & 235 & 311 & 0 & & & \\
\hline Kediri & 111,3 & 274 & 242 & 317 & 476 & 0 & & \\
\hline Jember & 113,3 & 331 & 237 & 290 & 282 & 273 & 0 & \\
\hline Mojokerto & 112,3 & 304 & 238 & 319 & 357 & 374 & 302 & 0 \\
\hline Demand & 62.000 & 35.560 & 228.120 & 93.920 & 184.600 & 49.880 & 136.440 & 48.520 \\
\hline
\end{tabular}

$$
\left(X_{1}, Y_{1}\right) \quad=\text { Original location }
$$

Table 1. Distance Matrix

After getting the distance matrix then using the defined. The results nearest neighbor algorithm sub routes is can be seen in Table 3 below.

Table 3. Sub Route formation result $(\mathrm{Km})$

\begin{tabular}{lrrrrrrrrr}
\hline Or./Des. & Route & Bojonegoro & Malang & Surabaya & Sidoarjo & Tulungagung & Kediri & Jember & Mojokerto \\
\hline Bojonegoro & 1 & 0 & & & & & & & \\
Malang & 2 & 111,3 & 0 & & & & & & \\
Surabaya & 3 & 111,7 & 237 & 0 & & & & \\
Sidoarjo & 3 & 109,3 & 270 & $\mathbf{2 3 8}$ & 0 & & & \\
Tulungagung & 4 & 111,3 & 370 & 235 & 311 & 0 & & \\
Kediri & 4 & 111,3 & 274 & 242 & 317 & $\mathbf{4 7 6}$ & 0 & \\
Jember & 2 & 113,3 & $\mathbf{3 3 1}$ & 237 & 290 & 282 & 273 & 0 & \\
Mojokerto & 3 & 112,3 & 304 & $\mathbf{2 3 8}$ & 319 & 357 & 374 & 302 & 0 \\
\hline \multicolumn{1}{c}{ Demand } & 62000 & 35560 & 228120 & 93920 & 184600 & 49880 & 136440 & 48520 \\
\hline
\end{tabular}

Based on Tables 3 and 4, the following sub routes are obtained:

a) Route 1: Bojonegoro with a total load of $62,000 \mathrm{~kg}$

b) Route 2: Malang, Jember with a total load of $172,000 \mathrm{~kg}$

c) Route 3: Surabaya, Sidoarjo, Mojokerto with a total load of $370,560 \mathrm{~kg}$

d) Route 5: Kediri, Tulungagung with a total load of $234,480 \mathrm{~kg}$

e) The alternative route has a total distance of $1970.6 \mathrm{~km}$ while the actual route is 3146.6 $\mathrm{km}$
IV. CONCLUSION

Conclusions that can be drawn from the research conducted includes:

1) The resulting sub-routes are four routes from the original eight shipping routes

2) The total saving generated in this research is $1176 \mathrm{Km}$.

3) The use of transportation vehicles to be more efficient 
Tibuana

Journal of applied Industrial Engineering-University of PGRI Adi Buana

DOI : https://doi.org/10.36456/tibuana.4.02.3749.65-68

\section{ACKNOWLEDGMENT}

The author would like to thank all those who

\section{REFERENCES}

[1] Zhang, X. X. Research on logistics distribution routing optimization based on ant colony algorithm. In Proc. of the Sixth International Forum on Decision Sciences, Springer, Singapore, 2020, pp. 65-78.

[2] Nguyen, L., Moseson, A. J., Farnam, Y., and Spatari, S., Effects of composition and transportation logistics on environmental, energy and cost metrics for the production of alternative cementitious binders, Journal of Cleaner Production, 2018, Vol. 185, pp. 628-645.

[3] Salehi, M., Jalalian, M., and Siar, M. M. V., Green transportation scheduling with speed control: trade-off between total transportation cost and carbon emission. Computers and Industrial Engineering, 2017, Vol.113, pp. 392-404.

[4] Kaur, H., and Singh, S. P., Heuristic modeling for sustainable procurement and logistics in a supply chain using big data. Computers and Operations Research, 2018, Vol. 98, 301-321.

[5] Kahraman, A., and Kazançoğlu, ., Understanding consumers' purchase intentions toward natural claimed products: A qualitative research in personal care products. Business Strategy and the Environment, 2019, Vol. 28 Ed. 6, pp.12181233.

[6] Guo, K., Research on location selection model of distribution network with constrained line constraints based on genetic algorithm. Neural Computing and Applications, 2020, Vol. 32 Ed. 6, 16791689.

[7] Heryanto, R., and Steephani, Y., Determination of Distribution Route using Linear Programming Model (Case Study at Washing Jeans Company). In 2019 1st helped in supporting the data so that this research can be realized.

International Conference on Engineering and Management in Industrial System (ICOEMIS 2019), Atlantis Press., Nov. 2019, pp. 253-259.

[8] Nurprihatin, F., Octa, A., Regina, T., Wijaya, T., Luin, J., and Tannady, H., The extension analysis of natural gas network location-routing design through the feasibility study. Journal of applied research on industrial engineering, 2019, Vol. 6 Ed. 2, pp. 108-124.

[9] Pattiasina, T. J., Setyoadi, E. T., and Wijayanto, D., "Saving matrix method for efficient distribution route based on google maps API" Journal of Telecommunication, Electronic and Computer Engineering (JTEC), 2018, Vol. 10 Ed. 2-3, pp. 183-188

[10] Rizkya, I., Matondang, N., Yahya, M. D., and Ningsih, M. S., Design of Distribution Routes Using Saving Matrix Method to Minimize Transportation Cost, In 2019 International Conference on Sustainable Engineering and Creative Computing (ICSECC), Aug. 2019, pp. 4851, IEEE.

[11] Rosanti, A. A., Sutopo, W., and Hisjam, M., Implementation of saving matrix to determine distribution route of Kalog Express Surakarta. In IOP Conference Series: Materials Science and Engineering, Apr. 2019, Vol. 495 Ed. 1, pp. 012025). IOP Publishing.

[12] Perdana, V. A., Hunusalela, Z. F., and Prasasty, A. T., Application of Saving Matrix and Nearest Neighbor to get the distribution route to achieve minimal transportation cost at PT. XYZ. JATI UNIK: Jurnal Ilmiah Teknik dan Manajemen Industri, 2020, Vol. 4 Ed.1, pp. 62-77. 